
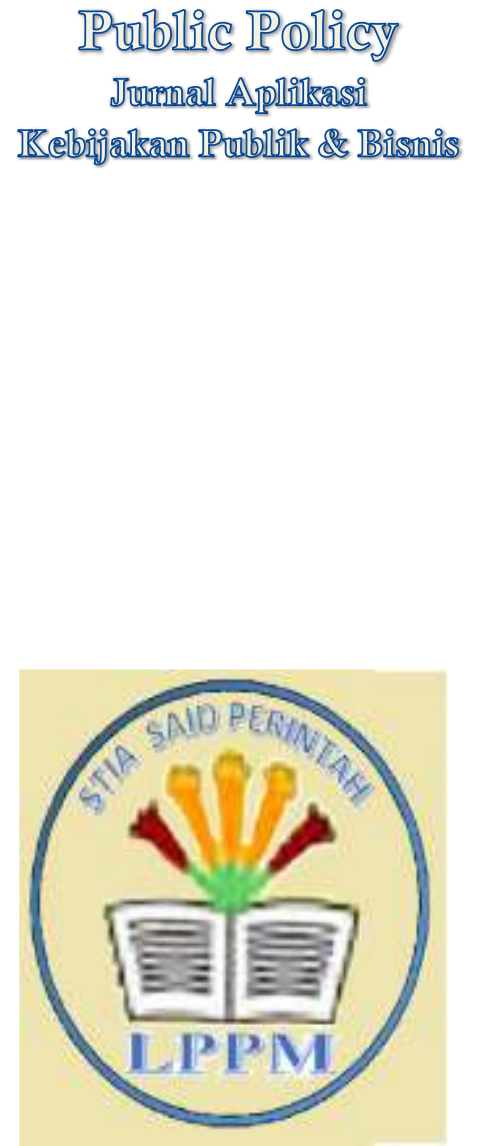

LPPM STIA Said Perintah

Volume 1, No. 2, September 2020

https://stia-saidperintah.e-journal.id/ppj

\section{Efek Moderasi Kontrol Diri pada \\ Hubungan Sifat Materialisme Terhadap \\ Pembelian Impulsif Online}

\author{
Dessy Balik \\ Fakultas Ekonomi Universitas Kristen Indonesia Maluku \\ Fenri Abraham Stevi Tupamahu \\ FKIP Universitas Pattimura \\ f2dtupamahu@gmail.com \\ (Penulis Korespondensi)
}

\begin{abstract}
This study aims to (1) examine the effect of materialism on impulsive online purchases. (2) To examine the moderating effect of self-control on the relationship between materialism and impulsive online purchases. This type of research is a causal research. The unit of analysis in this study is an individual lecturer at the Indonesian Christian University of Maluku (UKIM) as online shopping consumers who have made impulsive purchases online. The sampling method using nonprobability method, sampling using purposive sampling technique with the final sample of 48 people. Data analysis used thThe results of the study prove that materialism has an effect on impulsive online purchases.

The results of the study prove that materialism has an effect on impulsive online purchases. The nature of UKIM lecturers as consumers who emphasize the value of material, are selfish, want to have a lot of goods, and feel that ownership does not increase happiness, so that thoughtless buying behavior as a result, spontaneous purchases, rush purchases, and purchases are influenced by emotional states will increase. Consumers who have materialistic characteristics are classified as young consumers and have a high tendency to interact with social media with the potential to do impulsive shopping online. This study proves the impact of moderation of self-control as controlling consumer behavior in terms of valuing goods based on symbolic goods, social status, building social status from purchasing an item, and excessive prestige. The impact of self-control moderation has been shown to contribute to the influence of materialism on impulsive online purchases.
\end{abstract}

Keywords : Materialism, self-control, online impulsive buying 


\section{Pendahuluan}

Perubahan aktivitas bisnis di era digital atau era online saat ini, ditandai dengan integrasi teknologi informasi dalam hal penggunaan internet pada proses bisnis serta cenderung mengakibatkan perubahan terutama perilaku konsumen yang memiliki ketergantungan pada teknologi informasi terutama, dalam aktivitas pembelian atau belanja. Era digital, era online atau adopsi gaya hidup digital kini dijalani oleh sebagian besar masyarakat, terutama diperkotaan kondisi tersebut memungkinkan terjadi perubahan-perubahan yang telah mengubah mental, sikap, pola komunikasi, etika, struktur bahasa, meningkatnya konsumerisme, gaya hidup maupun cara pandang masyarakat (Sulistyaningtyas et al., 2012). Arisandy (2017) menjelaskan perubahan cara belanja untuk sebagian konsumen saat ini cenderung mengarah kepada cara yang lebih praktis dan canggih, yaitu dengan menggunakan teknologi informasi yang disebut belanja online.

Aktivitas belanja online dipandang menghemat waktu, dan merasa harga yang ditawarkan relatif lebih murah. Pembelian online berbeda dengan aktivitas pembelian offline atau cara pembelian konvensional, pembelian online tidak ada pertemuan langsung antara penjual dan pembeli, namun produk yang dibeli akan diantarkan ke alamat pembeli setelah ada kesepakatan. Belanja online tidak memerlukan mobilitas pembeli dan didukung kemudahan akses ke produk, kemudaan pembayaran dan penawaran yang diberikan, sehingga aktivitas belanja online dipandang praktis dan menjadi tren saat ini. Berbagai hasil penelitian membuktikan ragam determinan belanja online antara lain, Gefen et al (2003) dan Jublee \& Balamurugan (2016) menjelaskan bahwa kepercayaan merupakan dasar pembelian online. Hasil kajian Moshrefjavadi et al (2012) mengidentifikasi bahwa risiko keuangan dan risiko non-pengiriman memengaruhi sikap negatif terhadap belanja online. Namun Uzun \& Poturak (2014) dan Melis et al (2015) membuktikan hubungan antara kepuasan dengan layanan online, dan pengalaman belanja dan niat konsumen untuk membeli di masa depan yang menghasilkan loyalitas pelanggan dalam pembelian online.

Perkembangan belanja online sebagai dampak perkembangan teknologi sebagai manefestasi gaya hidup digital yang merupakan tren baru, dalam konteks aktivitas bisnis cenderung dapat mempengaruhi budaya, dan pola serta perilaku konsumsi. Perkembangan belanja online membuat transaksi semakin dinamis dalam ruang belanja yang relatif luas. Konsumen menjelaskan media online memengaruhi proses belanja, 
dan mereka berpendapat bahwa media online menginspirasi pembelian online mereka (Aragoncillo \& Orús, 2018). Karakteristik aktivitas belanja online cenderung berbasis pada media online atau media sosial memiliki berbagai kemudahan, memiliki banyak pilihan belanja, bersifat praktis dalam bentuk transaksi jual beli merupakan hal yang diinginkan oleh konsumen. Berbagai kemudahan, sifat praktis, ragam informasi serta ragam iklan online, memungkinkan psikologis konsumen terpengaruh, namun pada fase tertentu konsumen berpotensi melakukan pembelian secara tidak terencana atau tanpa pertimbangan yang matang (impulsive buying), melakukan pembelian secara tiba-tiba tanpa memikirkan kegunaan barang yang dibeli.

Hasil kajian Xiang et al., (2016) dan Aragoncillo \& Orús, (2018) menjelaskan peran media sosial sebagai alat yang ampuh untuk meningkatkan pembelian impulsif secara online. Margaret, (2016) menjelaskan bahwa berkembangnya e-commerce masyarakat akan lebih konsumtif, dan pada saat melihat barang-barang yang ada dihalaman website masyarakat akan cenderung untuk membeli barang tersebut diluar rencana (pembelian impulsif). Karakteristik pembelian produk melalui internet atau pembelian online sangat berpotensi untuk mendorong konsumen melakukan pembelian produk yang sebenarnya tidak mereka butuhkan (Miranda, 2016).

Pembelian impulsif online dalam prespektif psikologis cenderung merupakan dampak pengalihan perhatian konsumen oleh aplikasi maupun media online untuk memiliki sebuah produk. Pembelian impulsif online merupakan aktualisasi dorongan emosional terkait dengan adanya perasaan yang intens yang ditunjukkan dengan melakukan pembelian karena adanya dorongan untuk membeli suatu produk dengan segera, mengabaikan konsekuensi negatif, merasakan kepuasan dan mengalami konflik di dalam pemikiran (Verplanken \& Sato, 2011).

Secara umum pembelian impulsif online terbentuk dari fenomena belanja online serta kecenderungan interaksi pada media online relatif tinggi. Pendapat LaRose (2001) relevan dengan argument tersebut, menjelaskan internet mengontrol kapasitas konsumen dalam hal pembelian impulsif online. Media online menginformasikan ragam barang maupun jasa secara daring memiliki dampak besar serta cenderung mendorong perilaku pembelian impulsif secara online (Zhang et al., 2014; Aragoncillo \& Orús, 2018; Kumar \& Kaur, 2018). Pembelian online tidak dibatasi dalam waktu, jangkauan dan ketersediaan produk merupakan perangsang pembelian impulsif secara online (LaRose, 2001). Kenyamanan belanja online dianggap lebih baik dibandingkan belanja tradisional 
dan menguntungkan sebagian besar konsumen, hal ini mendorong pembelian impulsif (Dawson \& Kim, 2009). Pembelian impulsif online merupakan pembelian yang cenderung didasarkan pada situational influence dengan berbagai ragam determinan. Penelitian Sun \& Wu (2011); Chandra \& Purnami (2014); Winatha \& Sukaatmadja (2014); Zhang et al (2014); Margaret (2016) dan Ompi, A et al (2018) membuktikan faktor situasional sebagai pendorong pembelian impulsif online.

Perilaku pembelian impulsif online merupakan sebuah fenomena bagi masyarakat milenial dewasa ini yang dialami oleh semua lapisan masyarakat tanpa dibedakan dari status sosial maupun gender. Pendapat Sramova \& Pavelka (2019) relevan dengan argument tersebut, menjelaskan bahwa pada saat booming pemasaran digital, remaja laki-laki dan perempuan remaja memiliki motivasi hedonistik yang sama pada perilaku belanja online. Kondisi tersebut juga dimungkinkan dengan relevansi fenomena gaya hidup masyarakat, terutama masyarakat perkotaan. Masyarakat perkotaan merupakan masyarakat yang mobilitas tinggi serta relatif memiliki gaya hidup moderen serta gaya hidup dinamis memungkinkan masyarakat perkotaan memiliki budaya konsumtif yang relatif tinggi.

Budaya konsumtif yang tinggi identik atau mengarah pada sifat materialistis. Era digital atau era online cenderung mendorong masyarakat semakin mengadopsi budaya konsumen; budaya mendasari konsumen dengan penuh semangat menginginkan, mengejar, menggunakan, dan memamerkan barang dan jasa yang dianggap berharga daripada fungsinya, budaya ini cenderung memudahkan penyebaran nilai-nilai materialistik dalam suatu masyarakat (Bushra \& Bilal, 2014).

Materialisme adalah suatu sifat yang menganggap penting adanya kepemilikan terhadap suatu barang dalam hal menunjukan status dan membuatnya merasa senang (Schiffman \& Kanuk, 2010). Materialisme merupakan sifat psikologis konsumen yang berkembang menjadi gaya hidup serta cenderung mendasari karakteristik konsumen saat ini (Shahid et al., 2012). Hasil kajian empiris, Clark \& Ward (2008); Sun \& Wu (2011); Winatha \& Sukaatmadja (2014); Chandra \& Purnami (2014) dan Pundian (2017) membuktikan sifat materialisme secara positif mampu mempengaruhi seseorang untuk melakukan pembelian impulsif online, hal tersebut dibuktikan secara empiris oleh. Literatur dan hasil kajian empiris menjustifikasi keterkaitan antara sifat materialisme dengan perilaku pembelian tanpa direncanakan atau pembelian impulsif saat ini dipandang sebagai perilaku universial. 
Faktor lain yang dipandang memiliki keterkaitan dengan pembelian impulsif online selain sifat materialisme konsumen yakni kontrol diri (self contro). Dalam konteks resiko pembelian impulsif online bagi konsumen kontrol diri, dari segi psikologis memiliki relevansi rasional bagi konsumen. Calhoun dan Acocella (1995) dalam (Nurhaini, 2018) mendefinisikan kontrol diri sebagai pengaruh seseorang terhadap, dan peraturan tentang, fisiknya, tingkah laku, dan proses-proses psikologisnya dengan kata lain, sekelompok proses yang mengikat dirinya. Hasil penelitian Chita et al (2015) membuktikan hubungan negatif antara dukungan self-contro/dengan perilaku konsumtif online shopping. Individu konsumen yang memiliki self contro/yang rendah cenderung tidak mampu mengalihkan perhatian untuk memiliki produk yang baru (Hirschman \& Holbrook, 1982). Hasil penelitian Baumeister (2002).; Utami \& Sumaryono (2008); Nuraeni (2015) Pratiwi (2017) dan (Arisandy, 2017) membuktikan pengaruh kontrol diri terhadap pembelian impulsif online.

Sifat materialisme dan kontrol diri dipandang sebagai sifat alamiah manusia atau bersifat universial terutama berkaitan dengan perilaku konsumen masyarakat perkotaan. Masyarakat perkotaan, terutama yang berprofesi sebagai professional memiliki karakteristik hidup moderen atau gaya hidup metropolis merupakan fenomena perubahan sosial yang digambarkan memiliki mobilitas yang tinggi, sikap percaya pada ilmu pengetahuan dan teknologi, serta keterbukaan menerima kemajuan di bidang apa pun. Menurut klasifikasi Evans (2008) maupun Petrie \& McGee (2012) profesi dosen termasuk profesi professional. Dosen selalu menggunakan fasilitas moderen atau terbaru dalam mendukung pelaksanaan tugas, selain itu dosen relatif cepat mengadopsi berbagai perkembangan ilmu pengetahuan atau teknologi dalam aktivitas kerja maupun dalam kehidupan pribadi. Kondisi ini mengindikasikan bahwa dosen terbiasa dengan berbagai fasilitas atau barang moderen maupun yang terbaru.

Tupamahu (2018) menjelaskan bahwa perilaku di lingkungan kerja cenderung merupakan manefestasi perilaku pribadi, sebaliknya perilaku di lingkungan kerja cenderung mempengaruhi perilaku pribadi. Argumen tersebut mendasari asumsi bahwa kebiasaan menggunakan fasilitas terbaru atau moderen dapat berkaitan dengan terbentuk sifat yang menilai barang berdasarkan kegunaan penampilan dan berharga mahal, moderen, relevansi kepemilikan barang tertentu dengan status sosial. maupun prestise. Temuan Balik (2019) relevan dengan postulat tersebut yang menjelaskan fakta secara umum bahwa kecenderungan dosen mengadopsi gaya hidup moderen, 
indikasinya dosen terbiasa menggunakan fasilitas terbaru atau moderen serta sering berinteraksi dengan media online sehingga cenderung terbentuk pandangan bahwa sifat materialistik relatif terintegrasi dalam kehidupannya.

Fakta tersebut mendasari postulat bahwa dosen selaku profesional berpotensi memiliki sifat materialisme, maupun interaksi online shopping. Sifat materialistik terintegrasi dalam kehidupan pribadi serta memiliki interaksi dengan aktivitas online shopping dipandang sebagai pendorong pembelian impulsif online (Sari, 2013; Winatha \& Sukaatmadja, 2014). Namun hasil penelitian Chavosh et al (2011) membuktikan bahwa sifat materialisme tidak mempengaruhi pembelian impulsif online. Disisi lain Kacen \& Lee (2002) berpendapat bahwa konsumen melakukan pembelian impulsif lebih sedikit secara online daripada offline. Hasil penelitian Ozen \& Engizek (2014) menunjukkan bahwa pembeli online lebih cenderung impulsif dibandingkan pembeli tradisional.

Pada umumnya pembelian impulsif dipandang sebagai pembelian yang tidak rasional dan dihubungkan dengan pembelian yang cepat tanpa direncanakan, diikuti oleh adanya konflik pikiran dan dorongan emosional. Pembelian impulsif online dipandang memiliki resiko bagi konsumen, Bong (2011) menyatakan bahwa pembelian impulsif online hanya memiliki dampak positif bagi pelaku industri ritel, yaitu dalam hal keuntungan dan berkontribusi pada pendapatan industri ritel. Hasil observasi awal mengungkapkan, 20 orang dosen UKIM yang melakukan pembelian online, 16 orang diantaranya melakukan pembelian impulsif online serta merasa dampak negatif sebagai konsekuensi pembelian impulsif online. Perilaku pembelian impulsif merupakan perilaku pembelian spontan, namun cenderung berpotensi menimbulkan dampak negatif pada konsumen. Perilaku impulsive buying memiliki dampak negatif bagi pelakunya, antara lain adanya permasalahan dengan keuangan, merasa menyesal atau kecewa dengan barang yang didapat, serta menyadari bahwa apa yang dikeluarkan tidak sesuai dengan apa yang dibayangkan (Aragoncillo \& Orús, 2018).

Penjelasan litaratur, hasil kajian empiris maupun fakta mengungkapkan penjelasan yang relatif berbeda tentang pembelian impulsif online, maupun konsekuensi dari pembelian impulsif online. Fokus kajian penelitian terdahulu menjelaskan determinan pembelian impulsif online, namun relatif kurang dalam kajian atau eksplorasi konsekuensi pembelian impulsif online bagi konsumen. Konsumen di era online atau era gaya hidup digital terutama yang berprofesi sebagai professional memiliki mobilitas yang 
tinggi dan keterbatasan waktu sehingga sering melakukan pembelian online, namun relatif terjebak dalam pembelian impulsif serta mengalami konsekuensi negatif dari pembelian impulsif online, maka penting dilakukan penelitian ini guna menginvestigasi model kontrol konsekuensi pembelian impulsif online. Pengembangan investigasi penelitian ini guna pembuktian secara empiris interaksi aspek psikologis konsumen dalam hal keterkaitan atau interaksi sifat materialisme dengan kontrol diri sebagai suatu pendekatan kontrol perilaku konsumen dan pengaruhnya terhadap pembelian impulsif online. Penelitian ini bertujuan untuk (1) menguji pengaruh sifat materialisme terhadap pembelian impulsif online. (2) Menguji efek moderasi kontrol diri pada hubungan sifat materialisme terhadap pembelian impulsif online.

\section{Kerangka Teoritis Dan Pengembangan Hipotesis Sifat Materialisme}

Sifat materialisme merupakan salah satu sifat individu masyarakat di dunia, termasuk masyarakat Indonesia. Sifat materialisme dapat ditemukan di berbagai lapisan masyarakat, sifat materialism diindikasikan dari keadaan yang mana kepemilikan barangbarang mewah di Indonesia cenderung tidak didasarkan pada status, kasta maupun pangkat (Winatha \& Sukaatmadja, 2014). Materialisme diartikan sebagai cara individu guna memperoleh uang, status, dan barang-barang, hal tersebut merupakan kombinasi dari berbagai prinsip yang membuat tujuan materialistis sebagai simbol dari pencapaian, sedangkan barang-barang dipertimbangkan sebagai bagian penting dari kehidupan dan semakin banyak barang akan menyediakan kepuasan yang lebih (Iqbal \& Aslam, 2016).

Materialisme adalah suatu sifat yang menganggap penting adanya kepemilikan terhadap suatu barang dalam hal menunjukan status dan membuatnya merasa senang (Schiffman dan Kanuk, 2008 dalam Winatha \& Sukaatmadja, 2014). Konsumen materialistik cenderung masih mudah dan sangat memperhatikan penampilannya, pembelian yang cenderung tidak direncanakan dan membeli lebih banyak dari yang dibutuhkan (Joung, 2013). Sifat materialisme dalam masyarakat memungkinkan individu memperoleh keunggulan sosial, dan berfungsi sebagai simbol materialistik yang menyatakan status sosial mereka, oleh karena itu individu yang memiliki sifat materialisme memanfaatkan kepentingan simbolik barang untuk membangun identitas pribadi yang lebih baik (Singh \& Nayak, 2015). Sifat materialisme menilai barang berdasarkan kegunaan penampilan dan berharga mahal, kemampuan untuk membawa 
status sosial, kesuksesan, dan prestise (Ruswanti, 2015). Materialisme umumnya dianggap sebagai nilai negatif, sifat atau perilaku, terkait dengan keserakahan, kedangkalan, dan kurangnya nilai spiritual (Lipovčan et al., 2015).

\section{Kontrol Diri (Self Contro)}

Self-contro/didefinisikan sebagai keputusan individu melalui pertimbangan kognitif guna menyatukan perilaku yang telah disusun untuk meningkatkan hasil atau pencapaian tujuan tertentu sebagaimana yang diinginkan (Chita et al., 2015). Calhoun dan Acocella (1995) dalam (Nurhaini, 2018) mendefinisikan kontrol diri (self contro) sebagai pengaruh seseorang terhadap, dan peraturan tentang, fisiknya, tingkah laku, dan proses-proses psikologisnya dengan kata lain, sekelompok proses yang mengikat dirinya. Putri (2017) dalam Intan (2020) menjelaskan self control atau kontrol diri merupakan sifat kepribadian dimana sifat tersebut dapat mempengaruhi seseorang dalam membeli barang dan jasa. Kontrol diri merupakan reaksi yang ditujukan untuk mengganti sesuatu dengan yang lain, misalnya reaksi saat mengalihkan perhatian dari suatu hal yang diinginkan, mengubah emosi, menahan dorongan tertentu (Nurhaini, 2018).

Heni (2013) menjelaskan self-control memiliki tiga aspek, yaitu mengontrol perilaku (behavioral control), mengontrol kognitif (behavioral control) dan mengontrol keputusan (behavioral decisional). Chatijah \& Purwadi (2007) mendefinisikan serta mengkonsepkan self control atau control diri sebagai berikut, (1) Mampu merespon suatu stimulus yang secara langsung memperoleh keadaan tidak menyenangkan dan langsung mengantisipasinya. (2) Mengolah informasi yang tidak diinginkan, dengan menilai atau menghubungkan suatu kejadian dengan mengurangi tekanan. (3) Mampu untuk memilih hasil atau suatu tindakan berdasarkan pada suatu yang diyakin.

\section{Pembelian Impulsif Online}

Pembelian impulsif atau pembelian tidak terencana pada dasarnya merupakan tindakan pembelian yang dibuat tanpa direncanakan sebelumnya, atau keputusan pembelian dilakukan pada saat berada di dalam toko (Ompi, A et al., 2018). Pembelian impulsif dinyatakan sebagai suatu perilaku pembelian yang muncul tanpa dilandasi oleh adanya kebutuhan serta rencana pembelian yang terarah (Engel et al., 2001). Verplanken \& Herabadi (2001) mengkonsepkan pembelian impulsif sebagai sebagai suatu konsep perilaku yang dapat dikenali melalui 2 (dua) elemen, yakni kognisi dan emosi. 
Pembelian impulsif adalah pembelian yang terjadi ketika seseorang mengalami dorongan yang terkadang tidak tertahankan untuk mendapatkan suatu produk tanpa pertimbangan yang matang tentang mengapa dan untuk alasan apa seseorang membeli produk tersebut (Verhagen \& Van Dolen, 2011). Rook (1987) menjelaskan bahwa impulsive buying terdapat 3 kunci utama yaitu, pembelian yang tidak direncanakan, sulit untuk dikontrol, dan adanya respon emosional didalamnya. Impulsive buying terjadi karena konsumen mengalami dorongan secara tiba-tiba dan kuat juga terus-menerus untuk membeli sesuatu dengan segera.

Pendorong pembelian impulsive sangat beragam, Chen et al (2013) aspek sosial dalam hal kekompakan kelompok yang tinggi dan kerentanan yang tinggi berpengaruh terhadap perilaku pembelian impulsif. Pembelian impulsif online dapat dipamami sebagai perilaku seseorang mengalami dorongan secara tiba-tiba dan tidak tertahankan guna mendapatkan atau membeli suatu produk tanpa pertimbangan yang matang pada bisnis yang terjadi dalam jaringan elektronik seperti internet. Pembelian impulsif online dapat dimaknai sebagai tindakan pembelian yang dibuat tanpa direncanakan sebelumnya, atau keputusan pembelian dilakukan pada online shopping.

\section{Pengembangan Hipotesis}

Konsumen cenderung berpandangan bahwa perilaku pembelian online merupakan hal yang rasional dalam hal mencari informasi dan membuat perbandingan sebelum membuat keputusan akhir. Namun pembelian online menunjukan perilaku konsumen yang relatif beragam, hal ini tergambar dari perilaku pembelian impulsif. Pembelian impulsif online. Pembelian impulsif online merupakan dorongan untuk melakukan pembelian di median online atau di toko online secara tiba-tiba. Berkembangnya $e$ commerce masyarakat akan lebih konsumtif, dan pada saat melihat barang-barang yang ada dihalaman website masyarakat akan cenderung untuk membeli barang tersebut diluar rencana (Margaret, 2016).

Perkembangan cepat teknologi informasi yang dikenal dengan era digital atau era online cenderung membentuk gaya hidup atau sifat materialistis di kalangan masyarakat. Materialisme adalah suatu sifat yang menganggap penting adanya kepemilikan terhadap suatu barang dalam hal menunjukan status dan membuatnya merasa senang (Schiffman \& Kanuk, 2010). Impulsive buying dipengaruhi aspek sosial ekonomi, dimana orangorang mengidentifikasi dirinya terhadap oang lain atas dasar materi sehingga adanya kecenderungan untuk memamerkan barang yang mereka miliki, dan mereka merasakan 
kebahagiaan atau kepuasan terlepas dari barang tersebut mereka perlukan atau tidak (Iram \& Chacharkar, 2017). Secara empiris sifat materialisme dibuktikan sebagai determinan pembelian impulsif online. Hasil kajian Winatha \& Sukaatmadja (2014) membuktikan bahwa sifat materialisme cenderung mengutamakan simbolik barang serta menilai barang dihubungkan dengan status sosial, kesuksesan, dan prestise, terbukti mempengaruhi seseorang untuk melakukan pembelian impulsif. Pembuktian empiris tersebut didukung hasil kajian empiris oleh Clark \& Ward (2008), Sun \& Wu (2011), Chandra \& Purnami (2014) dan Pundian (2017) membuktikan pengaruh positif sifat materialistis terhadap pembelian impulsif online. Berdasarkan penjelasan literatur dan penelitian terdahulu, maka diajukan hipotesis penelitian, sebagai berikut;

Hipotesis 1 ; Sifat materialisme konsumen berpengaruh positif terhadap perilaku pembelian impulsif online.

Pembelian impulsif online dipandang sebagai perilaku yang kompleks, dalam konteks resiko pembelian impulsif online bagi konsumen kontrol diri dari segi psikologis memiliki relevansi rasional bagi konsumen. Kontrol diri merupakan sifat kepribadian dimana sifat tersebut dapat mempengaruhi seseorang dalam membeli barang dan jasa, dalam hal ini pembelian secara online. Hasil penelitian Chita et al (2015) membuktikan hubungan negatif antara dukungan self-control dengan perilaku konsumtif online shopping. Hasil penelitian Utami \& Sumaryono (2008); Nuraeni (2015) Pratiwi (2017) dan (Arisandy, 2017) membuktikan pengaruh negetif kontrol diri terhadap pembelian impulsif online. Keterkaitan kontrol diri dengan pembelian impulsif online maupun sifat materialisme relatif kompleks.

Sifat materialisme cenderung dipandang memiliki resiko negatif bagi konsumen dalam hal pembelian. Hasil penelitian Winatha \& Sukaatmadja, (2014) menjelaskan bahwa sifat materialisme tidak berperan sebagai variabel moderasi bagi pembelian impulsif online. Aspek pribadi konsumen atau mental diri mengontrol pembelian impulsif online (Lao, 2013). Secara psikologis kontrol diri berperan sebagai kontrol dalam perilaku konsumen (Nurhaini, 2018; Intan, 2020). Semakin tinggi kontrol diri maka berbagai konsekuensi negatif perilaku konsumen dapat dikontrol. Hal tersebut mendasari asumsi kontrol diri memiliki peran interaksi dengan sifat materialisme dalam hubungannya dengan pembelian impulsif online. Berdasarkan penjelasan literatur dan penelitian terdahulu, maka diajukan hipotesis penelitian, sebagai berikut; 
Hipotesis 2 ; Kontrol diri berperan sebagai moderasi pengaruh sifat materialisme terhadap pembelian impulsif online.

\section{Metode Penelitian}

\section{Desain Penelitian}

Jenis penelitian ini merupakan riset causal, yang menjelaskan hubungan kausal atau hubungan sebab akibat yang terjadi antara variabel bebas dan variabel terikat serta variabel pemoderasi dan merupakan model riset hypothesis testing. Horizon waktu penelitian ini adalah cross sectional. Unit analisis pada penelitian ini adalah individu dosen Universitas Kristen Indonesia Maluku (UKIM) selaku konsumen online shopping yang pernah melakukan pembelian impulsif secara online. Metode pengambilan sampel menggunakan metode nonprobabilitas, (metode penentuan sampel, dimana elemen populasi tidak memiliki kesempatan yang sama untuk dijadikan sampel), pengambilan sampel menggunakan teknik purposive sampling (Ferdinand, 2011).

Penentuan sampel berdasarkan pertimbangan (judgment sampling), dengan kriteria yakni, (1) dosen tetap Universitas Kristen Indonesia Maluku (UKIM), dan (2) dosen yang pernah melakukan pembelian impulsif secara online. Berdasarkan jumlah kuisioner yang terkumpul kembali serta kelengkapan data pada kuisionar, jumlah sampel yang dianalisis dalam penelitian ini sebanyak 48 orang. Jenis data dalam penelitian ini adalah primer dan merupakan data kuantitatif. Proses pengumpulan data menggunakan teknik pengumpulan data survey, dengan menggunakan cara penyebaran instrument kuisioner, pengukuran data menggunakan skala likert.

\section{Teknik Analisis Data}

Analisis data penelitian ini merupakan pengujian antar variabel, secara konseptual kerangka model analisis dijelaskan pada gambar 1 berikut ini.

\section{Model Analisis}

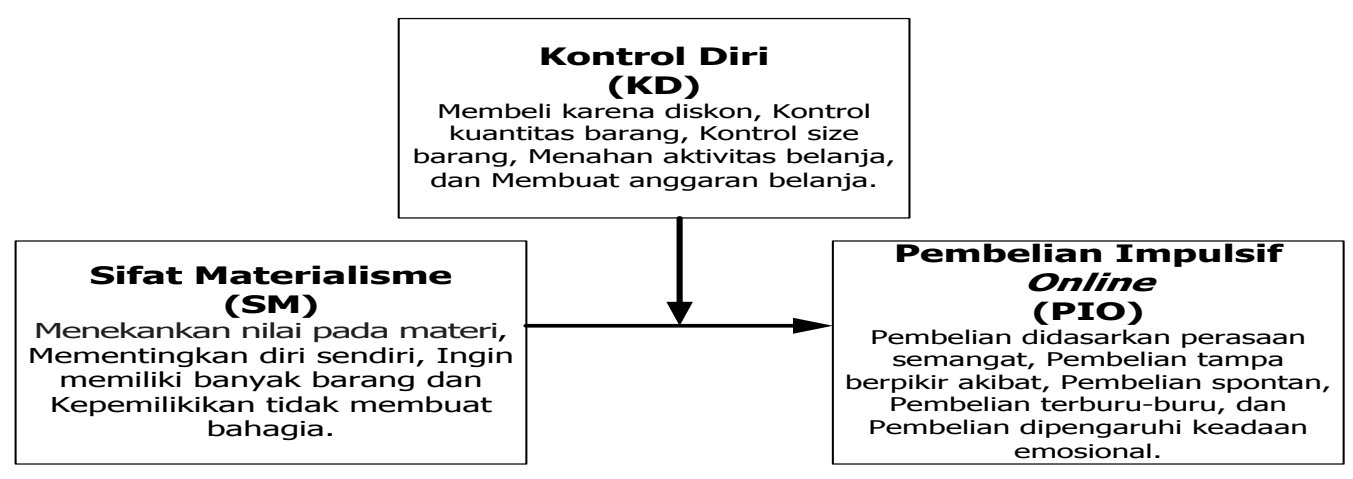


Analisis data menggunakan metode statistik Moderated Regression Analysis. Persamaan moderated regression adalah:

$\mathrm{PIO}=\mathrm{a}+\beta 1 \mathrm{SM}+\beta 2 \mathrm{SM} * \mathrm{KD}+\varepsilon$

Keterangan:

PIO = Pembelian Impulsif Online

$\mathrm{SM}=$ Sifat Materialisme

$\mathrm{KD}=$ Kontrol Diri

$\mathrm{a}=$ Konstanta

$\varepsilon=$ Error

$\beta=$ Koefisien regresi

\section{Pembahasan Hasil Penelitian}

\section{Uji Validitas Dan Reliabilitas}

Hasil uji instrumen dengan menggunakan uji validitas dan reliabilitas. Hasil uji validitas dijelaskan pada tabel berikut ini.

\section{Hasil Uji Validitas}

\begin{tabular}{|c|c|c|c|}
\hline $\begin{array}{c}\text { Item } \\
\text { Variabel }\end{array}$ & $\begin{array}{c}\text { Nilai } \\
\text { Korelasi } \\
(\mathrm{r})\end{array}$ & Nilai sig & Keterangan \\
\hline $\mathrm{sm} .1$ & 0.880 & 0.000 & Valid \\
\hline sm.2 & 0.847 & 0.000 & Valid \\
\hline $\mathrm{sm} .3$ & 0.892 & 0.000 & Valid \\
\hline $\mathrm{sm} .4$ & 0.766 & 0.000 & Valid \\
\hline sm.5 & 0.906 & 0.000 & Valid \\
\hline sm. 6 & 0.943 & 0.000 & Valid \\
\hline sm.7 & 0.937 & 0.000 & Valid \\
\hline $\mathrm{sm} .8$ & 0.880 & 0.000 & Valid \\
\hline sm.9 & 0.847 & 0.000 & Valid \\
\hline sm.10 & 0.892 & 0.000 & Valid \\
\hline sm.11 & 0.766 & 0.000 & Valid \\
\hline sm.12 & 0.906 & 0.000 & Valid \\
\hline sm.13 & 0.943 & 0.000 & Valid \\
\hline sm.14 & 0.948 & 0.000 & Valid \\
\hline kd.1 & 0.780 & 0.000 & Valid \\
\hline $\mathrm{kd} .2$ & 0.851 & 0.000 & Valid \\
\hline kd.3 & 0.856 & 0.000 & Valid \\
\hline kd.4 & 0.861 & 0.000 & Valid \\
\hline kd.5 & 0.807 & 0.000 & Valid \\
\hline kd. 6 & 0.685 & 0.000 & Valid \\
\hline kd.7 & 0.852 & 0.000 & Valid \\
\hline $\mathrm{kd} .8$ & 0.840 & 0.000 & Valid \\
\hline pio. 1 & 0.963 & 0.000 & Valid \\
\hline pio. 2 & 0.952 & 0.000 & Valid \\
\hline pio. 3 & 0.965 & 0.000 & Valid \\
\hline pio.4 & 0.953 & 0.000 & Valid \\
\hline pio. 5 & 0.973 & 0.000 & Valid \\
\hline pio. 6 & 0.948 & 0.000 & Valid \\
\hline pio.7 & 0.958 & 0.000 & Valid \\
\hline pio. 8 & 0.976 & 0.000 & Valid \\
\hline pio. 9 & 0.894 & 0.000 & Valid \\
\hline
\end{tabular}


Hasil uji instrumen dengan menggunakan uji reliabilitas dijelaskan pada tabel berikut ini.

\begin{tabular}{|c|c|c|}
\hline \multicolumn{3}{|c|}{$\begin{array}{l}\text { Hasil Uji Reliabilitas } \\
\text { Instrumen Penelitian }\end{array}$} \\
\hline Item Variabel & $\begin{array}{c}\text { Nilai } \\
\text { Cronbach } \\
\text { Apha } \\
\end{array}$ & Keterangan \\
\hline Sifat Materialisme & 0.978 & Reliable \\
\hline Kontrol Diri & 0.928 & Reliable \\
\hline $\begin{array}{l}\text { Pembelian Impulsif } \\
\text { Online }\end{array}$ & 0.986 & Reliable \\
\hline
\end{tabular}

Hasil uji validitas terhadap 31 indikator pada tiga variabel membuktikan bahwa nilai Nilai koefisien Product Moment $(r)$ tiap indikator lebih besar dari 0.4. Hasil uji reliabilitas dijelaskan pada tabel 2 menunjukan nilai cronbach alpha lebih besar dari 0.6. Hasil uji validitas dan reliabilitas membuktikan bahwa instrumen penelitian valid dan dapat dipercaya (reliable).

\section{Analisis Deskriptif}

Analisis deskriptif mendeskripsikan distribusi frekwensi jawaban responden berdasarkan data kuesioner yang telah disebarkan. Hasil analisis ini akan diperoleh gambaran tentang variable sifat materialisme, kontrol diri, dan pembelian impulsif online.

\section{Statistic Deskriptif}

\begin{tabular}{|c|c|c|c|c|c|c|}
\hline \multirow[b]{2}{*}{ Variabel } & \multirow[b]{2}{*}{$\mathrm{N}$} & \multirow[b]{2}{*}{ Minimum } & \multirow[b]{2}{*}{ Maximum } & \multicolumn{2}{|c|}{ Mean } & \multirow[b]{2}{*}{$\begin{array}{c}\text { Standard } \\
\text { Deviations }\end{array}$} \\
\hline & & & & Statistik & $\begin{array}{l}\text { Std } \\
\text { Error }\end{array}$ & \\
\hline \multirow{3}{*}{$\begin{array}{l}\text { Sifat Materialisme } \\
\text { (SM) } \\
\text { Kontrol Diri (KD) } \\
\text { Pembelian Impulsif Online } \\
\text { (PIO) }\end{array}$} & 48 & 21 & 70 & 55.04 & 2.141 & 14.834 \\
\hline & 48 & 11 & 40 & 31.73 & .927 & 6.731 \\
\hline & 48 & 11 & 45 & 35.71 & 1.667 & 11.546 \\
\hline
\end{tabular}

Deskripsi variabel penelitian dimaksudkan untuk menjelaskan seberapa besar persepsi responden terhadap indikator masing-masing variabel melalui pernyataan dalam kuesioner dalam ukuran statistic deskriptif. Hasil analisis deskriptif yang dijelaskan pada tabel 3 menjelaskan mean skor variabel sifat materialisme, kontrol diri, dan pembelian impulsif online menunjukan skor tinggi. Hasil analisis dekriptif menggambarkan skor persepsi responden terhadap variabel-variabel yang diteliti relatif tinggi.

\section{Uji Asumsi Klasik}


Pengujian asumsi klasik dalam kajian ini dimulai dari uji normalitas data. Uji normalitas data pada penelitian dilakukan dengan menggunakan grafik normal probability plot dengan melihat kecenderungan sebaran data terhadap garis regresi. Hasil analisis membuktikan bahwa titik-titik data menyebar di sekitar garis diagonal serta penyebarannya mengikuti arah garis diagonal, dengan demikian sebaran data dapat dikatakan relatif berdistribusi normal, sehingga bisa dilakukan uji regresi dengan Model Linear Berganda. Pengujian selanjutnya adalah uji heterokedastisitas yang dilakukan dengan cara melihat grafik plot antara nilai prediksi variabel dependen yaitu ZPRED dengan residuahya SRESID (Ghozali, 2013). Berdasarkan hasil analisis grafik plot semua titik yang ada menyebar di atas dan di bawah angka 0 pada sumbu $Y$, sehingga dapat disimpulkan bahwa model yang ada tidak mengalami heteroskedastisitas. Model analisis memungkinkan interaksi antar variabel sehingga uji multikolinearitas tidak dilakukan.

\section{Hasil Penelitian}

Hasil uji regresi moderasi, menggunakan model regresi pure moderator, model ini menjelaskan variabel moderator (MDR) tidak berhubungan dengan variabel Pembelian Impulsif Online (PIO), namun variabel moderator (MDR) berinteraksi dengan variabel prediktor sifat materialisme (SM). Hasil perhitungan regresi moderasi dijelaskan pada tabel 4 berikut ini;

Hasil Uji Regresi Moderasi

\begin{tabular}{ccccc}
\hline Variabel & $\begin{array}{c}\text { Standardized } \\
\text { Coefficients } \\
\text { (B) }\end{array}$ & t hitung & Sig. & Keterangan \\
\hline Constant & -0.453 & & & \\
Sifat Materialisme (SM) & 0.430 & 4.440 & 0.000 & Signifikan \\
Moderator & 0.007 & 3.207 & 0.002 & Signifikan \\
(MDR) & 0.927 & & & \\
R & 0.860 & & & \\
R Square & 138.131 & & & \\
F hitung & 0.000 & & & \\
Sign. F & & & \\
\hline
\end{tabular}

Model regresi berdasarkan hasil analisis dengan bantuan program SPSS dapat dibentuk persamaan Moderated Regression Analysis sebagai berikut :

$\mathrm{PIO}=-0.453+0.430 \mathrm{SM}+0.007 \mathrm{SM} * \mathrm{KD}$

Interpretasi dari persamaan tersebut adalah:

1. $\beta 1=0.430$ nilai parameter atau koefisien regresi $\beta 1$ menjelaskan bahwa setiap peningkatan variabel sifat materialisme (SM) diindikasikan, menekankan nilai pada 
materi, mementingkan diri sendiri, ingin memiliki banyak barang, dan kepemilikikan tidak membuat bahagia, maka pembelian impulsif online (PIO) akan meningkat sebesar nilai koefisien regresi $\beta 1$ atau pembelian impulsif online (PIO) dipengaruhi oleh variabel sifat materialisme (SM) sebesar 0.430 .

2. $\beta 2=0.007$ nilai parameter atau koefisien regresi $\beta 2$ menjelaskan bahwa variabel moderasi yakni kontrol diri (KD) diwakili oleh indikator karena diskon, kontrol kuantitas barang, kontrol size barang, menahan aktivitas belanja, dan membuat anggaran belanja terbukti mempengaruhi dalam arti berinteraksi atau mengontrol pengaruh sifat materialisme (SM) terhadap pembelian impulsif online (PIO) sebesar nilai koefisien regresi $\beta 2$ atau kontrol diri (KD) berinteraksi serta mempengaruhi pengaruh sifat materialisme terhadap pembelian impulsif online sebesar 0.007.

3. Nilai "R" sebesar 0.927 nilai ini membuktikan hubungan (korelasi) antara variabel sifat materialisme (SM) dan dampak variabel moderasi terhadap pembelian impulsif online (PIO) sebesar $92.8 \%$. Nilai "R" sebesar 0.860 , nilai ini menjelaskan determinasi (sumbangan) variabel materialisme (SM) dan dampak variabel moderasi terhadap pembelian impulsif online (PIO) sebesar $86 \%$, sedangkan $14 \%$ dijelaskan oleh faktor lain yang tidak dijelaskan dalam model.

Variabel sifat materialisme (SM) memiliki nilai t statistik/hitung sebesar 4.440 dan nilai sig 0.000 , nilai tersebut menjelaskan pembuktian signifikan pada level 0.05 ( $\rho<$ 0.05). Dengan demikian terbukti bahwa, terima $\mathrm{Ha}$ dan tolak $\mathrm{HO}$ atau hipotesis 1 diterima, hasil uji ini menjelaskan bahwa variabel sifat materialisme berpengaruh signifikan terhadap pembelian impulsif online. Nilai t statistik/hitung variabel moderasi sebesar 3.207 dan nilai sig 0.002, nilai tersebut menjelaskan pembuktian signifikan pada level 0.05 ( $\rho$ 0.05). Hasil ini membuktikan terima Ha dan tolak HO atau hipotesis 2 diterima, hasil uji tersebut menjelaskan realisasi perilaku kontrol diri berinteraksi serta mengontrol pengaruh sifat materialisme terhadap pembelian impulsif online.

\section{Pembahasan}

Penelitian ini membuktikan sifat materialisme berpengaruh terhadap pembelian impulsif online. Penelitian ini membuktikan bahwa sifat materialisme dalam hal menekankan nilai pada materi, mementingkan diri sendiri, ingin memiliki banyak barang, dan kepemilikikan tidak membuat bahagia mempengaruhi pembelian impulsif online meliputi, pembelian didasarkan perasaan semangat, pembelian tanpa berpikir 
akibat, pembelian spontan, pembelian terburu-buru, dan pembelian dipengaruhi keadaan emosional.

Hasil penelitian ini membuktikan bahwa responden yang memiliki sifat materialisme cenderung berpotensi yang lebih besar untuk melakukan belanja impulsive secara online. Berdasarkan analisis deskriptif, penelitian ini menemukan rata-rata responden berumur 33 tahun dan frekuensi interaksi dengan media sosial tergolong tinggi, hasil ini menjelaskan dosen UKIM yang memiliki sifat materialisme tergolong konsumen usia muda serta memiliki kecenderungan interaksi dengan media sosial yang tinggi berpotensi melakukan belanja impulsive secara online.

Penelitian ini mengungkapkan sifat materialisme yang menganggap penting objek barang penting yang dapat memposisikan status dan membuatnya merasa senang, tergolong berusia muda serta sering interaksi dengan media sosial merupakan pendorong pembelian impulsif online. Hasil penelitian mendukung hasil kajian Clark \& Ward (2008); Sun \& Wu (2011); Chandra \& Purnami (2014); Winatha \& Sukaatmadja (2014) dan Pundian (2017) menjelaskan pengaruh sifat materialistis terhadap perilaku pembelian impulsif online. Hasil penelitian ini juga relevan dengan temuan Iram \& Chacharkar (2017) yang membuktikan bahwa impulsive buying dipengaruhi aspek sosial ekonomi, dimana orang-orang mengidentifikasi dirinya terhadap oang lain atas dasar materi sehingga adanya kecenderungan untuk memamerkan barang yang mereka miliki, dan mereka merasakan kebahagiaan atau kepuasan terlepas dari barang tersebut mereka perlukan atau tidak. Namun hasil penelitian ini bertentangan dengan hasil kajian Chavosh et al (2011) yang membuktikan bahwa sifat materialisme tidak mempengaruhi pembelian impulsif online.

Hasil penelitian membuktikan kontrol diri sebagai variabel moderasi atau interaksi mempunyai pengaruh antara sifat materialisme dengan pembelian impulsif online. Kontrol diri yang diproxi dalam hal, membeli karena diskon, kontrol kuantitas barang, kontrol size barang, menahan aktivitas belanja, dan membuat anggaran belanja terbukti terbukti berinteraksi serta mengontrol pengaruh sifat materialisme terhadap pembelian impulsif online. Penelitian ini menjelaskan kontrol diri tidak sebagai variabel yang mempengaruhi langsung terhadap pembelian impulsif online oleh dosen UKIM, namun berinteraksi terhadap sifat materialisme. Dampak moderasi kontrol diri sebagai interaksi atau kontrol pada sifat materialisme terbukti mekanisme kontrol psikologis yang relevan perilaku konsuemen. 
Penelitian ini menjelaskan dampak moderasi kontrol diri sebagai interaksi psikologis dalam hal membeli karena diskon, membeli diluar perkiraan, menahan aktivitas belanja, dan membuat anggaran belanja. Kontrol diri merupakan sifat alamiah manusia, setiap individu tetap memiliki kontrol diri, walaupun memiliki sifat materialisme yang tinggi. Hasil penelitian ini menjelaskan kontrol diri dan sifat materialisme berinteraksi membentuk perilaku konsemen, dalam arti sama-sama dimiliki oleh individu konsuemen dan akan muncul dalam merespon dorongan untuk membeli suatu barang. Dampak moderasi kontrol diri sebagai pengontrol sifat konsumen dalam hal penilaian barang berdasarkan simbolik barang, status sosial, membangun status sosial dari pembelian suatu barang, serta prestise secara berlebihan.

Dampak moderasi kontrol diri terbukti berkontribusi pada pengaruh sifat materialisme terhadap pembelian impulsif online, dalam hal konsekuensi yang relatif negatif dari aktivitas pembelian impulsif online. Perkembangan teknologi informasi dan semakin tinggi interaksi konsumen dengan internet atau media sosial meningkatkan pembelian online dan pembelian impulsif online (Xiang et al., 2016; Miranda, 2016; Aragoncillo \& Orús, 2018; Kumar \& Kaur, 2018). Pembelian impulsif online saat ini dapat dilakukan oleh siapa saja tanpa memandang profesi, status, umur maupun gender. Pembelian impulsif online memiliki dampak negatif bagi konsumen (Bong, 2011; Aragoncillo \& Orús, 2018). Temuan penelitian ini sebagai solusi alternatif model empiris kontrol guna meminimalkan potensi dampak negatif perilaku pembelian impulsif pada konsumen.

Temuan penelitian ini menjelaskan kontribusi kontrol diri dalam hal mengontrol aktivitas pembelian impulsif yang paling layak, melakukan kontrol kuantitas maupun size barang yang dibeli sehingga sifat membeli berlebihan, serakah sebagai gambaran aktual sifat materialisme, maupun resiko atau dampak negatif pembelian impulsif online terkontrol. temuan penelitian ini relevan dengan hasil penelitian (Baumeister, 2002); Utami \& Sumaryono (2008); Nuraeni (2015); Pratiwi (2017) dan (Arisandy, 2017) membuktikan pengaruh kontrol diri terhadap pembelian impulsif online. Hasil penelitian ini melengkapi hasil kajian Sari (2013). Temuan penelitian ini relatif berbeda dengan hasil kajian Chita et al (2015) membuktikan hubungan negatif antara dukungan selfcontrol dengan perilaku konsumtif online shopping.

\section{Penutup}




\section{Kesimpulan}

Sifat materialisme yang dimiliki oleh dosen UKIM selaku konsumen berpengaruh terhadap pembelian impulsif online. Sifat materialisme konsumen yang menekankan nilai pada materi, mementingkan diri sendiri, ingin memiliki banyak barang, dan merasa kepemilikikan tidak membuat bahagia meningkat, mempengaruhi peningkatan perilaku pembelian tanpa berpikir akibat, pembelian spontan, pembelian terburu-buru, dan pembelian dipengaruhi keadaan emosional.

Konsumen yang memiliki sifat materialisme cenderung berpotensi yang lebih besar untuk melakukan belanja impulsive secara online. Temuan penelitian menjelaskan Konsumen yang memiliki sifat materialisme tergolong konsumen berusia muda serta memiliki kecenderungan interaksi dengan media sosial yang tinggi berpotensi melakukan belanja impulsive secara online.

Efek kontrol diri merupakan interaksi kontrol diri dan sifat materialisme membentuk perilaku konsemen, dalam arti sama-sama dimiliki oleh individu konsuemen dan akan muncul dalam merespon dorongan untuk membeli suatu barang. Dampak moderasi kontrol diri teraktualisasi sebagai pengontrol sifat konsumen dalam hal penilaian barang berdasarkan simbolik barang, status sosial, membangun status sosial dari pembelian suatu barang, serta prestise secara berlebihan. Dampak moderasi kontrol diri terbukti berkontribusi pada pengaruh sifat materialisme sebagai model kontrol terhadap pembelian impulsif online, dalam hal konsekuensi yang relatif negatif dari aktivitas pembelian impulsif online.

\section{Saran}

Diharapkan peneliti selanjutnya melakukan kajian pada subyek yang lebih banyak atau penambahan jumlah unit analisis misalnya kajian difokuskan pada generasi milenial. Peneliti selanjutnya perlu menyertakan atau menambah variabel yang bersifat holistik, misalnya aspek transendental ineteligence atau pengetahuan konsumen sebagai investigasi aspek individu dalam hal aktivitas belanja online guna melengkapi kajian ini dan diharapkan diperoleh pembuktian atau konsensus ilmiah tentang determinan pembelian impulsif online dapat lebih komprehensif.

\section{Daftar Pustaka}

Aragoncillo, L., \& Orús, C. (2018). Impulse Buying Behaviour: An Online-Offline Comparative And The Impact Of Social Media. Spanish Journal of Marketing - ESIC, 22(1), 42-62. https://doi.org/10.1108/SJME-03-2018-007

Arisandy, D. (2017). Kontrol Diri Ditinjau Dari Impulsive Buyying Pada Belanja Online. 
Jurnal IImiah PSYCHE, 11(1), 63-74.

Balik, D. (2019). Pengaruh Karakteristik Individu Dan Budaya Kerja Terhadap Kinerja Dosen Muda Universitas Kristen Indonesia Maluku Melalui Perilaku Knowledge Sharing ( Kajian Model Determinan Kinerja Dosen Dalam Memasuki Era Revolusi Industri 4.0 ). Prosiding Seminar Nasional \& Call Paper Prodi Pendidikan Ekonomi FKIP Universitas Pattimura, 109-125.

Baumeister, R. F. (2002). Yielding to Temptation: Self-Control Failure, Impulsive Purchasing, and Consumer Behavior. Journal of Consumer Research. https://doi.org/10.1086/338209

Bong, S. (2011). Pengaruh In-Store Stimuli Terhadap Impulse Buying Behavior Konsumen Hypermarket Di Jakarta. ULTIMA Management. https://doi.org/10.31937/manajemen.v3i1.175

Bushra, A., \& Bilal, A. (2014). The Relationship Of Compulsive Buying With Consumer Culture And Post-Purchase Regret. Pakistan Journal of Commerce and Social Sciences (PJCSS).

Chandra, I., \& Purnami, N. (2014). Pengaruh Jenis Kelamin, Promosi Penjualan Dan Sifat Materialisme Terhadap Perilaku Impulse Buying Secara Online. E-Jurnal Manajemen Universitas Udayana.

Chatijah, S., \& Purwadi. (2007). Hubungan Antara Religiusitas Dengan Sikap Konsumtif Remaja. Humanitas.

Chavosh, A., Halimi, a B., Namdar, J., Choshalyd, S. H., \& Abbaspour, B. (2011). The Contribution Of Product And Consumer Characteristics To Consumer's Impulse Purchasing Behaviour In Singapore. Social Science and Humanity, Pt One.

Chen, C.-Y., Lin, Y.-H., \& Chang, W.-M. (2013). Impulsive Purchasing Behavior for Professional Sports Team-Licensed Merchandise--From the Perspective of Group Effects. Sport Marketing Quarterly.

Chita, R. C. M., David, L., \& Pali, C. (2015). Hubungan Antara Self-Control Dengan Perilaku Konsumtif Online Shopping Produk Fashion Pada Mahasiswa Fakultas Kedokteran Universitas Sam Ratulangi Angkatan 2011. Jurnal E-Biomedik. https://doi.org/10.35790/ebm.3.1.2015.7124

Clark, J. M., \& Ward, S. G. (2008). Trait Predictors Of Online Impulsive Buying Tendency: A Hierarchical Approach. Journal of Marketing Theory and Practice. https://doi.org/10.2753/MTP

Dawson, S., \& Kim, M. (2009). External And Internal Trigger Cues Of Impulse Buying Online. Direct Marketing. https://doi.org/10.1108/17505930910945714

Engel, J. F., Blackwell, R. D., \& Miniard, P. W. (2001). Perilaku Konsumen, Jilid 2. Jakarta: Binarupa Aksara.

Evans, L. (2008). Professionalism, Professionality And The Development Of Education Professionals. British Journal of Educational Studies. https://doi.org/10.1111/j.1467-8527.2007.00392.x

Ferdinand, A. (2011). Metode Penelitian Manajemen Pedoman Penelitian untuk Penulisan Skripsi Tesis dan disertai Ilmu Manajemen. In Semarang: Universitas Diponegoro.

Gefen, D., Karahanna, E., \& Straub, D. W. (2003). Trust And Tam In Online Shopping: AN Integrated Model. MIS Quarterly: Management Information Systems. https://doi.org/10.2307/30036519

Ghozali, I. (2013). Aplikasi Analisis Multivariete. In Badan Penerbit Universitas Dipenegoro.

Heni, septi anugrah. (2013). Hubungan Antara Kontrol Diri Dan Syukur Dengan Perilaku Konsumtif Pada Remaja SMA IT Abu Bakar Yogyakarta. Empathy Jurnal Fakultas Psikologi. 
Hirschman, E. C., \& Holbrook, M. B. (1982). Hedonic Consumption: Emerging Concepts, Methods and Propositions. Journal of Marketing. https://doi.org/10.2307/1251707

Intan, A. (2020). Pengaruh Gaya Hidup, Religiusitas, Impulsif Buying, Hedonisme Dan Harga Terhadap Keputusan Pembelian Di Online Store Media Sosial Dengan Self Control Sebagai Variabel Intervening (Studi pada Mahasiswa Ekonomi Syariah Universitas Islam Negeri Sunan Ampel $d$. https://doi.org/10.1016/j.solener.2019.02.027

Iqbal, N., \& Aslam, N. (2016). Materialism, Depression, And Compulsive Buying Among University Students. The International Journal of Indian Psychology.

Iram, M., \& Chacharkar, D. D. Y. (2017). Model of Impulse Buying Behavior. BVIMSR's Journal of Management Research.

Joung, H. M. (2013). Materialism And Clothing Post-Purchase Behaviors. Journal of Consumer Marketing. https://doi.org/10.1108/JCM-08-2013-0666

Jublee, D., \& Balamurugan, R. N. (2016). How Does System Design Impact On Trust In Online Shopping Among Young Shoppers? Asian Journal of Research in Social Sciences and Humanities. https://doi.org/10.5958/2249-7315.2016.00837.6

Kacen, J. J., \& Lee, J. A. (2002). The Influence Of Culture On Consumer Impulsive Buying Behavior. Journal of Consumer Psychology. https://doi.org/10.1207/S15327663JCP1202_08

Kumar, S., \& Kaur, A. (2018). Understanding Online Impulsive Buying Behaviour of Students. International Journal of Management Studies. https://doi.org/10.18843/ijms/v5i3(1)/09

Lao, A. (2013). Mental Imagery And Its Determinants As Factors Of Consumers Emotional And Behavioural Responses: Situation Analysis In Online Shopping. Recherche et Applications En Marketing (English Edition). https://doi.org/10.1177/2051570713505479

LaRose, R. (2001). On The Negative Effects Of E-Commerce: A Sociocognitive Exploration Of Unregulated On-Line Buying. Journal of Computer-Mediated Communication. https://doi.org/10.1111/j.1083-6101.2001.tb00120.x

Lipovčan, L. K., Prizmić-Larsen, Z., \& Brkljačić, T. (2015). Materialism, Affective States, And Life Satisfaction: Case Of Croatia. SpringerPlus. https://doi.org/10.1186/s40064-015-1494-5

Margaret, O. (2016). Pengaruh Sifat Impulsif Dan Kualitas Website Terhadap Pembelian Impulsif Online Di Lazada. .

Melis, K., Campo, K., Breugelmans, E., \& Lamey, L. (2015). The Impact of the Multichannel Retail Mix on Online Store Choice: Does Online Experience Matter? Journal of Retailing. https://doi.org/10.1016/j.jretai.2014.12.004

Miranda, Y. C. (2016). Kajian Terhadap Faktor yang Mempengaruhi Impulse Buying dalam Online Shopping. Kompetensi.

Moshrefjavadi, M. H., Rezaie Dolatabadi, H., Nourbakhsh, M., Poursaeedi, A., \& Asadollahi, A. (2012). An Analysis of Factors Affecting on Online Shopping Behavior of Consumers. International Journal of Marketing Studies. https://doi.org/10.5539/ijms.v4n5p81

Nuraeni. (2015). Pengaruh Literasi Ekonomi, Kelompok Teman Sebaya Dan Kontrol Diri Terhadap Perilaku Pembelian Implusif Untuk Produk Fashion Pada Mahasiswa Fakultas Ekonomi Universitas Negeri Yogyakarta. Journal of Banking and Finance. https://doi.org/10.1016/j.jbankfin.2017.09.006

Nurhaini, D. (2018). Pengaruh Konsep Diri dan Kontrol Diri Dengan Perilaku Konsumtif Terhadap Gadget Remaja SMAN 1 Tanah Grogot. Pengaruh Konsep Diri Dan Kontrol Diri Dengan Perilaku Konsumtif Terhadap Gadget Remaja SMAN 1 Tanah Grogot. 
Ompi, A, P., Sepang , Jantje, L., \& Wenas, Rudy, S. (2018). Analisis Faktor-Faktor Yang Menyebabkan Terjadinya Pembelian Impulsif Produk Fashion Di Outlet Cardinal Mega Mall Manado. Jurnal EMBA: Jurnal Riset Ekonomi, Manajemen, Bisnis Dan Akuntansi. https://doi.org/10.35794/emba.v6i4.21318

Ozen, H., \& Engizek, N. (2014). Shopping Online Without Thinking: Being Emotional Or Rational? Asia Pacific Journal of Marketing and Logistics. https://doi.org/10.1108/APJML-06-2013-0066

Petrie, K., \& McGee, C. (2012). Teacher Professional Development: Who Is The Learner? Australian Journal of Teacher Education. https://doi.org/10.14221/ajte.2012v37n2.7

Pratiwi, I. (2017). Pengaruh Literasi Ekonomi, Kelompok Teman Sebaya Dan Kontrol Diri Terhadap Perilaku Pembelian Impulsif Untuk Produk Fashion Di Online Shop Pada Mahasiswa Jurusan Pendidikan Ekonomi UNDIKSHA. Jurnal Pendidikan Ekonomi Undiksha. https://doi.org/10.23887/jjpe.v9i1.19994

Pundian, Y. (2017). Pengaruh Impulse Buying, Consumer Anxiety, Dan Escapism Terhadap Perilaku Compulsive Buying Pada Konsumen Sepatu Di Surabaya. (Doctoral Dissertation, Widya Mandala Catholic University Surabaya).

Rook, D. W. (1987). The Buying Impulse. Journal of Consumer Research. https://doi.org/10.1086/209105

Ruswanti, E. (2015). Analysis Of Materialism, Fashion Clothing, And Recreational Shopper Identity. Journal of Economics, Business, and Accountancy / Ventura. https://doi.org/10.14414/jebav.v17i3.359

Sari, Kartika, R. (2013). Pengaruh Kontrol Diri, Motivasi Dan Materialisme Terhadap Perilaku Pembelian Kompulsif (Survei Pada Mahasiswa Universitas Muhammadiyah Purworejo). SEGMEN Jurnal Manajemen Dan Bisnis, $9(1)$. https://doi.org/https://doi.org/10.37729/sjmb.v9i1.377

Schiffman, L. G., \& Kanuk, L. L. (2010). Consumer Behavior 10th Edition. In Pearson Education.

Shahid, R., Asif, K., Jamshed, khan K., Ahsan, A., \& Mah a Mobeen, A. (2012). The Impact Of Materialism On Compulsive Consumption In Pakistan. African Journal of Business Management. https://doi.org/10.5897/ajbm11.1870

Singh, R., \& Nayak, J. K. (2015). Life Stressors And Compulsive Buying Behaviour Among Adolescents In India. South Asian Journal of Global Business Research. https://doi.org/10.1108/sajgbr-08-2014-0054

Sramova, B., \& Pavelka, J. (2019). Gender Differences And Wellbeing Values In Adolescent Online Shopping. International Journal of Retail and Distribution Management. https://doi.org/10.1108/IJRDM-08-2017-0173

Sulistyaningtyas, T., Jaelani, J., \& Waskita, D. (2012). Perubahan Cara Pandang Dan Sikap Masyarakat Kota Bandung Akibat Pengaruh Gaya Hidup Digital. Jurnal Sosioteknologi, Edisi 27(11), 157-168.

Sun, T., \& Wu, G. (2011). Trait Predictors Of Online Impulsive Buying Tendency: A Hierarchical Approach. Journal of Marketing Theory and Practice. https://doi.org/10.2753/MTP1069-6679190307

Tupamahu, F. A. S. (2018). Kecerdasan Spiritual, Kohesivitas Kelompok, Sebagai Pendorong Organizational Citizenship Behavior Dan Kinerja Karyawan. Ekonomi Peluang.

Utami, F. A., \& Sumaryono. (2008). Pembelian Impulsif Ditinjau Dari Kontrol Diri Dan Jenis Kelamin Pada Remaja. Jurnal Psikologi Proyeksi.

Uzun, H., \& Poturak, M. (2014). Factors Affecting Online Shopping Behavior Of Consumers. European Journal Of Social And Human Sciences. 
Verhagen, T., \& Van Dolen, W. (2011). The Influence Of Online Store Beliefs On Consumer Online Impulse Buying: A Model And Empirical Application. Information and Management. https://doi.org/10.1016/j.im.2011.08.001

Verplanken, B., \& Herabadi, A. (2001). Individual Differences In Impulse Buying Tendency: Feeling And No Thinking. European Journal of Personality. https://doi.org/10.1002/per.423

Verplanken, B., \& Sato, A. (2011). The Psychology of Impulse Buying: An Integrative Self-Regulation Approach. Journal of Consumer Policy. https://doi.org/10.1007/s10603-011-9158-5

Winatha, R., \& Sukaatmadja, I. (2014). Pengaruh Sifat Materialisme Dan Kecanduan Internet Terhadap Perilaku Pembelian Impulsif Secara Online. E-Jurnal Manajemen Universitas Udayana.

Xiang, L., Zheng, X., Lee, M. K. O., \& Zhao, D. (2016). Exploring Consumers' Impulse Buying Behavior On Social Commerce Platform: The Role Of Parasocial Interaction. International Journal of Information Management. https://doi.org/10.1016/j.ijinfomgt.2015.11.002

Zhang, K. Z. K., Zhao, S. J., Cheung, C. M. K., \& Lee, M. K. O. (2014). Examining The Influence Of Online Reviews On Consumers' Decision-Making: A HeuristicSystematic Model. Decision Support Systems. https://doi.org/10.1016/j.dss.2014.08.005 